\title{
Ethnic Nepotism as a Cross-Cultural Background Factor of Ethnic Conflicts
}

\author{
Tatu Vanhanen \\ University of Helsinki, Helsinki, Finland \\ Email: tatu4@saunalahti.fi
}

Received 24 April 2014; revised 27 May 2014; accepted 11 June 2014

Copyright (C) 2014 by author and Scientific Research Publishing Inc. This work is licensed under the Creative Commons Attribution International License (CC BY). http://creativecommons.org/licenses/by/4.0/

c) (i) Open Access

\section{Abstract}

The purpose of this article has been to explore why ethnic conflicts tend to break out in all ethnically divided societies. The principal explanation was traced to the evolved disposition for ethnic nepotism shared by all human populations. Ethnic nepotism was measured roughly by the degree of ethnic heterogeneity of the populations. It was correlated with the scale of ethnic conflicts in the group of 187 countries. The results of correlation analysis indicate that ethnic heterogeneity explains 55\% of the variation in the scale of ethnic conflicts, and the results of regression analysis disclose that the same relationship more or less applies to all 187 countries. These results led to the conclusion that ethnic nepotism is the common cross-cultural background factor which supports the persistence of ethnic conflicts in the world as long as there are ethnically divided societies.

\section{Keywords}

Ethnic Nepotism, Ethnic Heterogeneity, Cross-Cultural, Conflicts

\section{Introduction}

The purpose of this article is to explore why some ethnic conflicts tend to break out in all ethnically divided societies, not only in some of them, but virtually in all of them, although the extent and intensity of conflicts may vary significantly. My intention is to seek a theoretical explanation for the fact that ethnic conflicts occur in all ethnically divided countries, not only in some of them. This comparative study covers 178 contemporary countries. However, the smallest countries, whose population was less than 100,000 inhabitants in 2010, are excluded from the sample of countries for the reason that it may be more difficult to find reliable data on ethnic cleavages and conflicts from mini states than that from bigger countries.

This is not my first study of ethnic conflicts. I have explored the same research problem in my previous books 
Politics of Ethnic Nepotism: India as an Example (1992), Ethnic Conflicts Explained by Ethnic Nepotism (1999) and Ethnic Conflicts: Their Biological Roots in Ethnic Nepotism (2012) as well as in several conference papers and articles. My first conference paper on ethnic nepotism "Politics of Ethnic Nepotism" was presented at the 10th European Conference on Modern South Asian Studies, September 28 to October 1, 1988, in Venice, Italy. The first article on this subject "Politics of Ethnic Nepotism in India" was published in a book Ethnicity and Political Development in South Asia, edited by Diethelm Weidemann, New Delhi. In this article I continue the same line of argumentation, but the number of countries is larger than that in any of my previous studies of ethnic conflicts and data are partly new and more recent ones.

\section{Previous Explanations of Ethnic Conflicts and Ethnic Nepotism}

It is characteristic for most previous explanations that various cultural, political, and other environmental factors are used to explain ethnic conflicts, whereas the impacts of human nature have not been considered see (Vanhanen, 2012: pp. 10-21). Smith's (1987, pp. 220-225) theoretical argument is that cultural pluralism and ethnic nationalism cause inter-ethnic tension and ethnic conflicts and those we should expect continual inter-ethnic conflicts in our world of very uneven political and economic resources. Rupesinghe (1988) argued that there is no single explanatory variable or a single mono-causal explanation for ethnic conflict. Ted Robert Gurr came to the conclusion that inequalities and discrimination are related to communal grievances that instigate the establishment of ethnic organizations and foment communal protests and rebellions. Gurr noted that these results are "consistent with conflict theories and emphasize the importance of group mobilization, but fail to address the most interesting theoretical question, which is why groups mobilize in the first place” (Gurr, 1993: p. 188). Giddens (1995: pp. 251-282) argues that ethnic prejudices are based on learned stereotypical thinking and on psychological mechanism of displacement He also claims that ethnic conflicts belong to the legacy of colonialism. These are only few examples of many highly interesting studies of ethnic conflicts. In most of these theoretical explanations, the emergence of ethnic conflict is related to various cultural and environmental factors. It is not easy to test those hypotheses by empirical evidence because hypotheses are not clearly stated, because the number of possible variables is large, or because it is not clear how the theoretical concepts could be operationalize.

As in my previous studies, I prefer primordialist conceptualization of ethnicity and seek ultimate explanations for ethnic conflicts from biological factors. Van den Berghe (1981) refers to the sociobiological explanation of nepotism and argues that ethnic sentiments evolved as an extension of nepotism. In other words, from the propensity to favor kin over non-kin. He used the term "ethnic nepotism" to describe such mutual aid networks based on kinship (for primordial and sociobiological explanations, see also Rushton, 1986; Goetze, 2001; Salter, 2003; Thayer, 2004). The evolutionary interpretation of ethnicity and ethnic conflict has been traced to William Hamilton's (1964) sociobiological theory of inclusive fitness or kin selection. According to his theory, it is genetically rational to behave altruistically toward relatives because relatives share more genes with us than with outsiders. I assume that all populations share cross-culturally the same disposition to ethnic nepotism, which makes it justified to hypothesize that the more deeply a population is ethnically divided, the more interest conflicts become canalized along ethnic lines see (Vanhanen, 2012: pp. 18-26). My intention is to test this hypothesis by empirical evidence on the degree of ethnic heterogeneity (which is a measure of ethnic nepotism) and ethnic conflicts and to see whether some alternative explanatory factors are able to explain as much or more of the extent of ethnic conflicts than ethnic heterogeneity.

\section{Variables}

The testing of the hypothesis presupposes that we have a variable that measures the extent of ethnic conflicts in a society (dependent variable) and another variable that measures the degree of ethnic heterogeneity in a society (explanatory variable). Besides, we can use some other variables as alternative explanatory variables to indicate how much they are able to explain of the extent of ethnic conflicts independently from the level of ethnic heterogeneity.

Ethnic conflict is one type of conflict between competing actors. In conflict conscious beings try to carry out mutually inconsistent acts concerning their wants and needs. In social group conflict two or more actors oppose each other in social interaction, reciprocally exerting social power in an effort to attain scarce or incompatible goals and prevent the opponent from attaining them. Ethnic conflict is a conflict between ethnic groups see (Wi- 
kipedia, 2014: Ethnic Conflict; Wikipedia, 2014: Conflict process). How to measure it? In fact, my book Ethnic Conflicts: Their Biological Roots in Ethnic Nepotism (2012) includes data on the Estimated Scale of Ethnic Conflicts (EEC). They concern principally the period 2003-2008. I have corrected and complemented this fivelevel scale of ethnic conflicts by more recent data of the years 2009-2014. In the five-level scale 5 indicates the highest level of ethnic conflicts and the scale 1 the lowest level of conflicts. This five-level scale will be used as the principal dependent variable.

The degree of ethnic heterogeneity will be used as the explanatory variable in this study, as it was used in my previous studies. It is assumed to measure the significance of ethnic nepotism, which is expected to explain the emergence of ethnic conflicts in ethnically heterogeneous countries, and my intention is to use it in this study to the same purpose. Ethnic nepotism does not explain the origin of conflicts, but it explains why so many interest conflicts in human societies take place between ethnic groups.

According to my theoretical argumentation, the most ultimate explanation for ethnic conflict can be traced to the continual struggle for existence and to our evolved disposition to ethnic nepotism. It is natural for the members of an ethnic group to support each other in various conflicts. Because of its evolutionary roots, our behavioral disposition to ethnic nepotism is shared by all human populations. Briefly stated, my basic hypothesis is that the more deeply a population is ethnically divided, the more interest conflicts become canalized along ethnic lines. The conflicts may vary from peaceful competition to utmost violence. The significance of ethnic nepotism is measured by the degree of ethnic heterogeneity, which is measured by the percentage of the largest ethnic group. Consequently, it is necessary in this study to seek empirical data on the ethnic structures of 187 countries and on the percentage of the largest ethnic group. Its percentage of the total population indicates the degree of ethnic homogeneity, and its inverse percentage indicates the degree of ethnic heterogeneity. I have collected these data from The CIA World Factbook 2014 (2013) and from some other sources.

Alternative explanatory variables used in this study include national IQ (the average intelligence of nations), Human Development Index (HDI), the Index of Economic Freedom, the Index of Democratization (ID), and GNI per capita (PPP).

\subsection{National IQ}

Data on national IQs measure general intelligence of people. It has been emphasized that intelligence means the ability to understand complex ideas, to adapt effectively to the environment, and to overcome obstacles (Lynn \& Vanhanen, 2012: pp. 9-34). Consequently, it is reasonable to assume that more intelligent nations are more able to solve their interest conflicts without violent means than less intelligent nations. It is interesting to see to what extent the results of statistical analysis support this assumption. Intelligence differences have been studied approximately 60 years. Richard Lynn has had a leading role in the study of intelligence differences between nations see (Nyborg, 2013: p. X). I began to co-operate with Lynn in 1999 and to produce comparative studies on the impact of intelligence differences to human conditions. We found that national IQ explains more of the variation in human conditions than any other explanatory variable. It is highly interesting to see whether this applies also to ethnic conflicts. In this study it is assumed that national IQ is an explanatory variable which is able to explain a significant part of the variation in ethnic conflicts, too. Empirical data on national IQs are taken from Lynn's and my book Intelligence: A Unifying Construct for the Social Sciences (2012).

\subsection{Human Development Index (HDI)}

This index is produced annually by the United Nations Development Programme (UNDP, 2013) and published by UNDP in its annual survey Human Development Report. The data used in this study concern the year 2012, and they are published in Human Development Report 2013: The Rise of the South: Human Progress in a Diverse World. The data cover 186 countries.

The HDI is a composite index measuring average achievement in three basic dimensions of human development: a long and healthy life (life expectancy at birth), knowledge (mean years of schooling and expected years of schooling), and a decent standard of living (gross national income per capita), PPP\$. Life expectancy at birth is measured by "number of years a newborn infant could expect to live if prevailing patterns of age specific mortality rates at the time of birth stay the same throughout the infant's life". Mean years of schooling refer to the average number of years of education received by people ages 25 and older. Expected years of schooling refer to the number of years of schooling a child can expect to receive, if prevailing patterns of enrolment rates 
persist throughout the child's life.

Finally, gross national income (GNI) per capita includes, briefly described, the aggregate income an economy generated by its production and its ownership of factors of production converted to international dollars using PPP rates, divided by midyear population. Empirical data on these variables and the composite index of the human development are available from Human Development Report 2013, Table 1. It should be noted that only data on HDI, not on its components, will be used in this study. They can be assumed to be highly reliable data.

\subsection{The Index of Economic Freedom}

The Heritage Foundation has collected and published data on economic freedom in their annual reports since the 1990s. According to their definition: "Economic freedom is the fundamental right of every human to control his or her own labor and property". This means that in an economically free society, people should be free to work, produce, consume, and invest in any way they please. It is noted that for much of human history, "most individuals have lacked economic freedom and opportunity, condemning them to poverty and deprivation". The idea behind the report seems to be that today we live in the most prosperous time in human history because of the advance of economic freedom. Their measure of economic freedom is based on 10 quantitative and qualitative factors, which are grouped into four broad categories of economic freedom: 1) rule of law, 2) limited government, 3) regulatory efficiency, and 4) open markets. Every component of the index is considered to be equally important (2014 Index of Economic Freedom: pp. 1-2). If the argumentation of the Heritage Foundation is correct, it would be reasonable to assume that the index is positively correlated with the inversed five-level scale of ethnic conflicts because it is justified to expect that economically free countries are better able to avoid serious ethnic conflicts than countries with a low level of economic freedom. Data in the 2014 index concern the year 2013.

\subsection{Index of Democratization (ID)}

Many conflicts take place in politics in which individuals, social groups and political parties struggle for power and dominance. Power is not shared equally between competitors, and the degree of power sharing varies greatly from highly democratic systems to autocracies. I have measured the degree of democratization by two empirical variables: by the smaller parties' share of the votes cast in parliamentary and/or presidential elections (competition) and by the percentage of the population who actually voted in these elections (participation). These two variables are combined into the Index of Democratization (ID) by multiplying the two percentages and by dividing the results by 100 . A country is regarded to be the more democratized, the higher the value of ID is see (Vanhanen, 1990: 11-24; 1997: 21-37; 2012: 36-40). Data on ID-2012 are from FSD1289 Measures of Democracy, 1810-2012).

The Index of Democratization is included into this study because it is an index which measures from one perspective the success of competing groups in the struggle for scarce resources. It is reasonable to assume that the struggle for power and resources is in stabilized democracies less violent than in countries for which the degree of ID is lower. However, the intensity of competition may be high in many democracies, too, but a crucial

Table 1. Correlations between the scale of ethnic conflits (EES) and explanatory variables as well as correlations between other variables.

\begin{tabular}{cccccccc}
\hline & EES & EH & National IQ & HDI-12 & EF-13 & ID-12 & Per capita income \\
\hline EES & .00 & -.745 & -.393 & -.529 & -.432 & -.323 & -.348 \\
EH & & .00 & .391 & .432 & .244 & .215 & .192 \\
National IQ & & .00 & .791 & .499 & .519 & .566 \\
HDI-12 & & & .00 & .606 & .586 & .737 \\
EF-12 & & & & .00 & .425 & .579 \\
ID-12 & & & & & .0 & .377 \\
Per capita income & & & & & & .0 \\
\hline
\end{tabular}


difference is that it remains more or less peaceful. Consequently, one could expect that correlation between the scale of ethnic conflicts and the level of ethnic heterogeneity is negative and that it is positive between the inversed scale of ethnic conflicts and ethnic heterogeneity.

\subsection{GNI per Capita (PPP)}

There are different indicators of per capita income. I am going to measure differences in per capita income in this study by gross national income (GNI) per capita (PPP\$) because the PPP version attempts to take into account the currency's real domestic purchasing power see (Nafziger 1997, pp. 21-26; Gardner, 1998: p. 22). Empirical data on this variable are given in Human Development Report 2013, Table 1). Because high per capita countries have managed their economic affairs better than low per capita countries, it is justified to assume that they have been able to avoid serious ethnic conflicts better than poorer countries. Consequently, this variable should be negatively correlated with the five-level scale of ethnic conflicts.

\section{Hypotheses Tested by Empirical Evidence}

Now the two principal empirical variables-the estimated five-level scale of ethnic conflicts (EEC) and the measure of ethnic heterogeneity (EH) —as well as the five alternative explanatory variables have been briefly introduced. The degree of ethnic heterogeneity and the five alternative explanatory variables can now be used to test hypotheses on their relationships to the five-level scale of ethnic conflicts, which is the dependent variable in this study. From various sources, I have collected data on ethnic conflicts and on the degree of ethnic heterogeneity. Such data are needed in estimations of the scale of ethnic conflicts (from 1 to 5) for each of the 187 countries. It should be noted that the values of the scale of ethnic conflicts are my estimations because there is not any numerical evidence on the scale differences between countries. The values of both principal research variables should be regarded as preliminary ones. A more detailed analysis of source material might give reasons to correct these variables in several cases. Anyway, the results of correlation analysis will indicate to what extent empirical evidence supports or contradicts the above hypotheses on the relationships between these explanatory variables and the level of ethnic conflicts.

Because the degree of ethnic heterogeneity is based on our evolved disposition to ethnic nepotism, it was assumed that it constitutes the principal explanatory variable, which may explain more of the variation in the scale of ethnic conflicts than any cultural or environmental variable. However, five alternative explanatory variables were selected to check the explanatory power of ethnic heterogeneity. Each of them was hypothesized to correlate negatively with the degree of ethnic conflicts and positively with the inversed scale of ethnic conflicts (EES). It is interesting to see how strongly they are related to EES. Correlations are given in Table 1.

The results of correlation analysis show that ethnic heterogeneity (EH) explains much more of the variation in the scale of ethnic conflicts (55.5\%) than any of the other variables (HDI 28\%). A weak correlation between national IQ and EES implies that EES is a characteristic of human nature, which is independent from national IQ. A high level of national IQ has not prevented the emergence of ethnic conflict. The lowest relationship between EES and alternative explanatory variables is in the case of ID-12, which implies that the level of democratization does not affect the scale of ethnic conflicts. However, because all alternative explanatory variables are to some extent related to EES, one could expect that together they might be able to explain as much or more of the variation in EES than EH alone. Is it true? The results of a multi-regression analysis, in which EH and the five alternative variables are used to explain the variation in EES, answer to this question. The multiple correlation based on the six explanatory variables rises to .777 and the squared correlation to .604. It is clearly higher than the simple correlation between EH and EES, but the explained part of variation is not more than $5 \%$ higher.

The results of correlation analysis show that ethnic heterogeneity explains 55\% of the global variation in EES, but how this relationship applies to single countries. Are ethnic conflicts concentrated to some parts of the world, or are they more or less evenly distributed around the world? One could expect a relatively equal distribution of EES rather than its concentration to some regions of the world. The results of a simple regression analysis, in which EH is the independent variable and EES the dependent variable, help to answer this question. The detailed results of the regression analysis of EES on EH for 187 countries (Table 2) disclose how well the average relationship between EH and EES applies to single countries.

The principal explanatory variable - the degree of ethnic heterogeneity-explains $55.5 \%$ of the variation in the scale of ethnic conflicts, but what about the impact of five alternative explanatory variables. Are they able to 
Table 2. The detailed results of regression analysis of EEC on EH for single countries in the group of 187 countries.

\begin{tabular}{|c|c|c|c|c|c|c|}
\hline & Country & Largest ethnic group & $\mathrm{EH}$ & EES & Residual EES & Fitted EES \\
\hline 1 & Afghanistan & Pashtun & 42 & 5 & 1.8 & 3.2 \\
\hline 2 & Albania & Albanian & 85 & 1 & -.6 & 1.6 \\
\hline 3 & Algeria & Arab & 83 & 1 & -.6 & 1.6 \\
\hline 4 & Andorra & Spanish Andorran & 76 & 1 & -.9 & 1.9 \\
\hline 5 & Angola & Ovimbundu & 37 & 3 & -.4 & 3.4 \\
\hline 6 & Antiqua \& Barbuda & Black & 91 & 1 & -.3 & 1.3 \\
\hline 7 & Argentina & White & 97 & 1 & -.1 & 1.1 \\
\hline 8 & Armenia & Armenian & 93 & 1 & -.2 & 1.2 \\
\hline 9 & Australia & White & 92 & 1 & -.3 & 1.3 \\
\hline 10 & Austria & Austrian & 91 & 1 & -.3 & 1.3 \\
\hline 11 & Azerbaijan & Azeri & 91 & 1 & -.3 & 1.3 \\
\hline 12 & Bahamas & Black & 85 & 1 & -.6 & 1.6 \\
\hline 13 & Bahrain & Bahraini & 46 & 3 & -.1 & 3.1 \\
\hline 14 & Bangladesh & Bengali & 45 & 2 & -1.1 & 3.1 \\
\hline 15 & Barbados & Black & 93 & 1 & -.2 & 1.2 \\
\hline 16 & Belarus & Belarusian & 84 & 1 & -.6 & 1.6 \\
\hline 17 & Belgium & Fleming & 58 & 2 & -.2 & 2.6 \\
\hline 18 & Belize & Mestizo \& creole & 73 & 2 & - & 2.0 \\
\hline 19 & Benin & Fon and relatives & 39 & 2 & -1.3 & 3.3 \\
\hline 20 & Bhutan & Bhote & 50 & 3 & .1 & 2.9 \\
\hline 21 & Bolivia & Mestizo and white & 45 & 3 & -.1 & 3.1 \\
\hline 22 & Bosnia \& Herzeg. & Bosniak & 48 & 3 & - & 3.0 \\
\hline 23 & Botswana & Tswana & 79 & 1 & -.8 & 1.8 \\
\hline 24 & Brazil & White & 54 & 3 & .2 & 2.8 \\
\hline 25 & Brunei & Malay & 66 & 2 & -.3 & 2.3 \\
\hline 26 & Bulgaria & Bulgarian & 77 & 2 & .1 & 1.9 \\
\hline 27 & Burkina Faso & Mossi & 40 & 3 & -.3 & 3.3 \\
\hline 28 & Burma (Myanmar) & Burman & 68 & 4 & 1.8 & 2.2 \\
\hline 29 & Burundi & Hutu & 85 & 3 & 1.4 & 1.6 \\
\hline 30 & Cambodia & Khmer & 90 & 2 & .6 & 1.4 \\
\hline 31 & Cameroon & Cam. Highlanders & 31 & 3 & -.7 & 3.7 \\
\hline 32 & Canada & European & 68 & 2 & -.2 & 2.2 \\
\hline 33 & Cape Verde & Creole & 71 & 1 & -1.1 & 2.1 \\
\hline 34 & Central Af. Republic & Baya & 33 & 4 & .4 & 3.6 \\
\hline 35 & Chad & Sara & 28 & 5 & 1.2 & 3.8 \\
\hline
\end{tabular}




\section{Continued}

\begin{tabular}{|c|c|c|c|c|c|c|}
\hline 36 & Chile & White \& white Am & 95 & 1 & -.2 & 1.2 \\
\hline 37 & China & Han Chinese & 91 & 2 & .7 & 1.3 \\
\hline 38 & Colombia & Mestizo & 58 & 3 & .4 & 2.6 \\
\hline 39 & Comoros & Sunni Muslim & 98 & 1 & -.1 & 1.1 \\
\hline 40 & Congo, Republic & Kongo & 48 & 4 & 1.0 & 3.0 \\
\hline 41 & Congo, Dem Rep. & Kongo & 45 & 5 & 1.9 & 3.1 \\
\hline 42 & Costa Rica & White & 94 & 1 & -.2 & 1.2 \\
\hline 43 & Cote d'Ivoire & Akan & 42 & 4 & .8 & 3.2 \\
\hline 44 & Croatia & Croat & 90 & 1 & -.4 & 1.4 \\
\hline 45 & Cuba & White & 65 & 2 & -.3 & 2.3 \\
\hline 46 & Cyprus & Greek & 77 & 1 & -.9 & 1.9 \\
\hline 47 & Czech Republic & Czech & 64 & 1 & -1.4 & 2.4 \\
\hline 48 & Denmark & Danish descend & 90 & 1 & -.4 & 1.4 \\
\hline 49 & Djibouti & Somali & 60 & 3 & .5 & 2.5 \\
\hline 50 & Dominica & Black & 87 & 1 & -.5 & 1.5 \\
\hline 51 & Dominican Rep. & Mixed & 73 & 2 & - & 2.0 \\
\hline 52 & Ecuador & Mestizo & 71 & 2 & -.1 & 2.1 \\
\hline 53 & Egypti & Sunni Muslim & 94 & 2 & .8 & 1.2 \\
\hline 54 & El Salvador & Mestizo & 86 & 1 & -.5 & 1.5 \\
\hline 55 & Equatorial Guinea & Fang & 86 & 1 & -.5 & 1.5 \\
\hline 56 & Eritrea & Tigrinya & 55 & 3 & .3 & 2.7 \\
\hline 57 & Estonia & Estonian & 69 & 2 & -.2 & 2.2 \\
\hline 58 & Ethiopia & Oromo & 35 & 3 & -.5 & 3.5 \\
\hline 59 & Fiji & Fijian & 57 & 3 & .4 & 2.6 \\
\hline 60 & Finland & Finn & 93 & 1 & -.2 & 1.2 \\
\hline 61 & France & Frenz & 92 & 1 & -.3 & 1.3 \\
\hline 62 & Gabon & Bantu tribes & 90 & 1 & -4 & 1.4 \\
\hline 63 & Gambia & Mandinka & 34 & 3 & -.5 & 3.5 \\
\hline 64 & Georgia & Georgian & 84 & 2 & .4 & 1.6 \\
\hline 65 & Germany & German & 92 & 1 & -.3 & 1.3 \\
\hline 66 & Ghana & Akan & 48 & 2 & -1.0 & 3.0 \\
\hline 67 & Greece & Greek & 93 & 1 & -.2 & 1.2 \\
\hline 68 & Grenada & Black & 82 & 1 & -.7 & 1.7 \\
\hline 69 & Guatemala & Mestizo an Europ. & 59 & 3 & .4 & 2.6 \\
\hline 70 & Guinea & Peuhl & 40 & 3 & -.3 & 3.3 \\
\hline 71 & Guinea-Bissau & Balante & 30 & 3 & -.7 & 3.7 \\
\hline
\end{tabular}




\section{Continued}

\begin{tabular}{|c|c|c|c|c|c|c|}
\hline 72 & Guayana & East Indian & 43 & 3 & -.2 & 3.2 \\
\hline 73 & Haiti & Black & 95 & 1 & -.2 & 1.2 \\
\hline 74 & Honduras & Mestizo & 90 & 2 & .6 & 1.4 \\
\hline 75 & Hungary & Hungarian & 92 & 1 & -.3 & 1.3 \\
\hline 76 & Iceland & Norse and Celtic & 94 & 1 & -.2 & 1.2 \\
\hline 77 & India & Indo-Aryan & 72 & 3 & .9 & 2.1 \\
\hline 78 & Indonesia & Jawanese & 41 & 4 & .7 & 3.3 \\
\hline 79 & Iran & Persian & 61 & 3 & .5 & 2.5 \\
\hline 80 & Iraq & Arab & 75 & 4 & 2.1 & 1.9 \\
\hline 81 & Ireland & Irish & 87 & 1 & -.5 & 1.5 \\
\hline 82 & Israel & Jewish & 76 & 3 & 1.1 & 1.9 \\
\hline 83 & Italy & Italian & 94 & 1 & -.2 & 1.2 \\
\hline 84 & Jamaica & Black & 91 & 1 & -.3 & 1.3 \\
\hline 85 & Japan & Japanese & 98 & 1 & -.1 & 1.1 \\
\hline 86 & Jordan & Arab & 98 & 1 & -.1 & 1.1 \\
\hline 87 & Kazakhstan & Kazakh & 63 & 2 & -.4 & 2.4 \\
\hline 88 & Kenya & Kikuyu & 17 & 4 & -.2 & 4.2 \\
\hline 89 & Kiribati & Micronesian & 99 & 1 & - & 1.0 \\
\hline 90 & Kuwait & Arab & 80 & 2 & .2 & 1.8 \\
\hline 91 & Kyrgyztan & Kyrgyz & 65 & 3 & .7 & 2.3 \\
\hline 92 & Laos & Lao & 55 & 3 & .3 & 2.7 \\
\hline 93 & Latvia & Latvian & 59 & 2 & -.6 & 2.6 \\
\hline 94 & Lebanon & Arab & 93 & 2 & .8 & 1.2 \\
\hline 95 & Lesotho & Sotho & 99 & 1 & - & 1.0 \\
\hline 96 & Liberia & Kpelle & 20 & 5 & .9 & 4.1 \\
\hline 97 & Libya & Arab & 89 & 2 & .6 & 1.4 \\
\hline 98 & Lithuania & Lithuanian & 84 & 1 & -.6 & 1.6 \\
\hline 99 & Luxembourg & Luxembourger & 63 & 1 & -1.4 & 2.4 \\
\hline 100 & Macedonia & Macedonian & 64 & 3 & .6 & 2.4 \\
\hline 101 & Madagascar & Merina & 26 & 3 & -.9 & 3.9 \\
\hline 102 & Malawi & Chewa & 33 & 3 & -.6 & 3.6 \\
\hline 103 & Malaysia & Malay & 50 & 3 & .1 & 2.9 \\
\hline 104 & Maldives & Maldivian & 98 & 1 & -.1 & 1.1 \\
\hline 105 & Mali & Mande & 50 & 3 & .1 & 2.9 \\
\hline 106 & Malta & Maltese & 95 & 1 & -.2 & 1.2 \\
\hline 107 & Marshall Islands & Marshallese & 92 & 1 & -.3 & 1.3 \\
\hline
\end{tabular}




\section{Continued}

\begin{tabular}{|c|c|c|c|c|c|c|}
\hline 108 & Mauritania & Moor/black & 40 & 3 & -.3 & 3.3 \\
\hline 109 & Mauritius & Indo-Mauritian & 68 & 2 & -.2 & 2.2 \\
\hline 110 & Mexico & Mestizo & 60 & 2 & -.5 & 2.5 \\
\hline 111 & Micronesia & Chuukese & 49 & 1 & -2.0 & 3.0 \\
\hline 112 & Moldova & Moldovan & 64 & 2 & -.4 & 2.4 \\
\hline 113 & Mongolia & Mongol & 95 & 1 & -.2 & 1.2 \\
\hline 114 & Montenegro & Montenegrin & 43 & 3 & -.2 & 3.2 \\
\hline 115 & Morocco & Arab-Berber & 99 & 1 & 1.0 & 1.0 \\
\hline 117 & Namibia & Blsck & 87 & 2 & 1.0 & 1.0 \\
\hline 118 & Nepal & Nepali & 48 & 4 & 1.0 & 3.0 \\
\hline 119 & Netherlands & Dutch & 81 & 1 & -.7 & 1.7 \\
\hline 120 & New Zealand & European & 57 & 2 & -.6 & 2.6 \\
\hline 121 & Nicaragua & Mestizo & 69 & 2 & -.2 & 2.2 \\
\hline 122 & Niger & Haoussa & 55 & 3 & .3 & 2.7 \\
\hline 123 & Nigeria & Hausa and Fulani & 29 & 5 & 1.3 & 3.7 \\
\hline 124 & Norway & Norwegian & 94 & 1 & -.2 & 1.2 \\
\hline 125 & North Korea & Korean & 100 & 1 & - & 1.0 \\
\hline 126 & Oman & Omani Arab & 73 & 2 & - & 2.0 \\
\hline 127 & Pakistan & Punjabi & 45 & 4 & .9 & 3.1 \\
\hline 128 & Panama & Mestizo & 70 & 2 & -.1 & 2.1 \\
\hline 129 & Papua New Guinea & Papuan & 84 & 2 & .4 & 1.6 \\
\hline 130 & Paraguay & Mestizo & 95 & 1 & -.2 & 1.2 \\
\hline 131 & Peru & Amerindian & 45 & 3 & -.1 & 3.1 \\
\hline 132 & Philippines & Takalog & 28 & 3 & -.8 & 3.8 \\
\hline 133 & Poland & Polish & 97 & 1 & -.1 & 1.1 \\
\hline 134 & Portugal & Portuguese & 98 & 1 & -.1 & 1.1 \\
\hline 135 & Qatar & Arab & 40 & 3 & -.3 & 3.3 \\
\hline 136 & Romania & Romanian & 90 & 1 & -.4 & 1.4 \\
\hline 137 & Russia & Russian & 80 & 3 & 1.2 & 1.8 \\
\hline 138 & Rwanda & Hutu & 84 & 3 & 1.4 & 1.6 \\
\hline 139 & Saint Kitts \& Nevis & Black & 90 & 1 & -.4 & 1.4 \\
\hline 140 & Saint Lucia & Black & 89 & 1 & .4 & 1.4 \\
\hline 141 & Saint Vincent & Black & 60 & 1 & -1.5 & 2.5 \\
\hline 142 & Samoa & Samoan & 93 & 1 & -.2 & 1.2 \\
\hline 143 & Sao Tome \& Pr. & Creoles & 85 & 1 & -.6 & 1.6 \\
\hline 144 & Saudi Arabia & Arab & 90 & 2 & .6 & 1.4 \\
\hline
\end{tabular}




\section{Continued}

\begin{tabular}{|c|c|c|c|c|c|c|}
\hline 145 & Senegal & Wolof & 43 & 4 & .8 & 3.2 \\
\hline 146 & Serbia & Serb & 83 & 2 & .4 & 1.6 \\
\hline 147 & Seychelles & Creole & 92 & 1 & .3 & 1.3 \\
\hline 148 & Sierra Leone & Temne & 35 & 4 & .5 & 3.5 \\
\hline 149 & Singapore & Chienese & 77 & 2 & .1 & 1.9 \\
\hline 150 & Slovakia & Slovak & 86 & 1 & -.5 & 1.5 \\
\hline 151 & Slovenia & Slovene & 83 & 1 & -.6 & 1.6 \\
\hline 152 & Solomon Islands & Melanesian & 94 & 1 & -.2 & 1.2 \\
\hline 153 & Somalia & Somali & 85 & 5 & 3.4 & 1.6 \\
\hline 154 & South Africa & Black & 79 & 3 & 1.2 & 1.8 \\
\hline 155 & South Korea & Korean & 99 & 1 & - & 1.0 \\
\hline 156 & Spain & Castilian Spanish & 74 & 2 & - & 2.0 \\
\hline 157 & Sri Lanka & Sinhalese & 74 & 4 & 2.0 & 2.0 \\
\hline 158 & Sudan & Sudanese Arab & 70 & 5 & 2.9 & 2.1 \\
\hline 159 & Suriname & Hindustani & 37 & 3 & -.4 & 3.4 \\
\hline 160 & Swaziland & Swazi & 82 & 1 & -.7 & 1.7 \\
\hline 161 & Sweden & Swedish & 89 & 1 & -.4 & 1.4 \\
\hline 162 & Switzerland & German & 65 & 2 & -.3 & 2.3 \\
\hline 163 & Syria & Arab & 90 & 2 & .6 & 1.4 \\
\hline 164 & Taiwan & Taiwanese & 84 & 1 & -.6 & 1.6 \\
\hline 165 & Tajikistan & Tajik & 80 & 2 & .2 & 1.8 \\
\hline 166 & Tanzania & Bantu African & 95 & 1 & -.2 & 1.2 \\
\hline 167 & Thailand & Thai & 75 & 3 & 1.1 & 1.9 \\
\hline 168 & Timor-Leste & Roman Catholic & 86 & 3 & 1.5 & 1.5 \\
\hline 169 & Togo & Ewe-Adja & 43 & 3 & -.2 & 3.2 \\
\hline 170 & Tonga & Tongan & 95 & 1 & -.2 & 1.2 \\
\hline 171 & Trinidad \& Tobago & Indian & 40 & 3 & -.3 & 3.3 \\
\hline 172 & Tunisia & Arab & 96 & 1 & -.1 & 1.1 \\
\hline 173 & Turkey & Turkish & 70 & 3 & .9 & 2.1 \\
\hline 174 & Turkmenistan & Turkmen & 85 & 1 & -.6 & 1.6 \\
\hline 175 & Uganda & Potestant & 42 & 3 & -.2 & 3.2 \\
\hline 176 & Ukraine & Ukrainian & 78 & 3 & 12 & 1.8 \\
\hline 177 & United Arab Emirates & Arab & 48 & 2 & -.1 .0 & 3.0 \\
\hline 178 & United Kingdom & White & 84 & 1 & -.6 & 1.6 \\
\hline 179 & United States & White & 80 & 1 & -.8 & 1.8 \\
\hline 180 & Uruguay & White & 88 & 1 & -.4 & 1.4 \\
\hline
\end{tabular}




\begin{tabular}{ccccccc} 
Continued & & & & & \\
\hline 181 & Uzbekistan & Uzbek & 80 & 1 & -.8 & 1.8 \\
182 & Vanuatu & Ni-Vanuatu & 98 & 1 & -.1 & 1.1 \\
183 & Venezuela & Mestizo & 67 & 2 & -.3 & 2.3 \\
184 & Vietnam & Viet & 87 & 2 & .5 & 1.5 \\
185 & Yemen & Arab & 80 & 1 & -.8 & 1.8 \\
186 & Zambia & African & 99 & 1 &. & 1.0 \\
187 & Zimbabwe & African & 98 & 2 & .9 & 1.1 \\
\hline
\end{tabular}

increase significantly the explained part of variation in the measure of ethnic conflicts independently from the degree of ethnic heterogeneity? The results of a multi-regression analysis show that their impact is quite limited. When they are added to a multi-regression model, the explained part of variation in EES rises from $55 \%$ to $60 \%$, which means that they explain only $5 \%$ of the variation in the scale of ethnic conflicts independently from the degree of ethnic heterogeneity. The level of ethnic heterogeneity seems to be by far the best explanatory variable.

Table 2 shows the results of regression analysis of EES on EH for 187 single countries. It is easy to note that the values of EES and EH are not evenly distributed in the world. Some countries with large positive or negative residuals deviate considerably from the average relationship between the degree of ethnic heterogeneity (EH) and the scale of ethnic conflicts (EES). We can see from Table 2 the most deviating countries. Of course, the borderline between the most deviating and less deviating countries is arbitrary. Let us use one standard deviation in residual EES (0.8) to separate large deviations from the less deviating countries. Using this criterion, the group of large positive deviations includes the following 28 countries: Afghanistan, Burma, Burundi, Chad, Republic of Congo, Democratic Republic of Congo, Cote d'Ivoire, Egypt, India, Iraq, Israel, Lebanon, Liberia, Nepal, Nigeria, Pakistan, Russia, Rwanda, Senegal, Somalia, South Africa, Sri Lanka, Sudan, Thailand, TimorLeste, Turkey, Ukraine, and Zimbabwe. In all these countries, the level of ethnic conflicts is considerably higher than expected on the basis of the regression equation.

Using the same criterion, the group of large negative residuals includes the following 17 countries: Andorra, Bangladesh, Benin, Botswana, Cape Verde, Cyprus, Czech Republic, Ghana, Luxembourg, Madagascar, Micronesia, Philippines, Saint Vincent, United Arab Emirates, United States, Uzbekistan, and Yemen. For all these countries, the estimated level of ethnic conflicts is clearly lower than expected on the basis of the regression equation.

The combined number of large positive and negative residuals rises to 45 , which is $25 \%$ of the total number of 178 countries. Large positive residuals are clearly more numerous (28) than negative ones (17). More than half of the countries with large positive residuals are African countries (15), and ten of them are Asian countries. Latin American countries are without any large positive residuals, and in Europe there are only two countries with large positive residuals and in Oceania one. This means that the countries with large positive residuals are concentrated to Africa and Asia. Such regional concentration may be partly due to the impact of cultural and environmental factors.

The countries with large negative residuals are much more evenly distributed around the world. This category includes 5 African, 5 Asian, and 5 European and North American countries, but only one Latin American and one Oceania country.

The principal explanatory variable - the degree of ethnic heterogeneity (EG) - seems to be able to explain 55 percent of the variation in the scale of ethnic conflicts. The rest of the variation (45\%) can be assumed to be due to measurement errors, to accidental factors, and to the impact of cultural and environmental factors. In each deviating case it would be useful to explore what those environmental factors have been, but in this brief article such a detailed analysis is not possible.

In this connection, somebody could argue that correlation between ethnic heterogeneity and ethnic conflicts is more or less natural one because ethnic conflicts cannot happen in a society without any ethnic divisions. It is true that ethnic cleavages are needed for the emergence of ethnic conflicts, but it should be noted that ethnic cleavages do not need to lead automatically to ethnic conflicts. If cultural interpretations are true, it would be 
quite possible that there are not any ethnic conflicts even in some ethnically deeply divided societies. Such societies would live without any ethnic conflicts, whereas the most significant ethnic conflicts might occur in some less divided societies. However, we can see from Table 2 that the distribution of countries with large residuals does not follow such culturally determined pattern. The degree of ethnic heterogeneity seems to be the common factor behind small and serious ethnic conflicts in culturally quite different parts of the world. Consequently, it is justified to conclude that ethnic nepotism is a cross-cultural background factor of ethnic conflicts.

\section{Conclusion}

It was noted in the Introduction that the purpose of this article is to explore the emergence of ethnic conflicts in all ethnically divided societies and to seek a theoretical explanation for the universality and persistence of these conflicts. I criticized earlier theoretical explanations for their tendency to pay attention only to some cultural and other environmental factors and to forget the possibility that the ultimate explanation for the persistence of ethnic conflicts might be in human nature. I prefer the primordial conceptualization of ethnicity and trace my explanation to the sociobiological theory of ethnic nepotism. According to this theory, it is genetically rational to support relatives because we share more genes with relatives than that with outsiders. From this perspective, ethnic groups are extended family groups. I assume that all human populations are cross-culturally aware the same evolved disposition to ethnic nepotism, which explains the universality of ethnic conflicts and makes it justified to hypothesize that the more deeply a population is ethnically divided, the more interest conflicts become canalized along ethnic lines.

I tested this hypothesis by empirical evidence on the level of ethnic conflicts and the degree of ethnic heterogeneity, and checked the results by some alternative explanatory variables. The results of correlation analyses indicate that ethnic heterogeneity of the population (EH) explains $55 \%$ of the variation in the five-level scale of ethnic conflicts (EES), whereas the best alternative explanatory variable (HDI-12) does not explain more than $28 \%$ of the variation in EES. The results of multi-regression analysis, in which all five alternative explanatory variables (national IQ, HDI-12, Economic Freedom, ID-12, and GNI per capita income) together with the degree of ethnic heterogeneity are used to explain the variation in EES, show that the explained part of variation in EES rises from $55 \%$ to $60 \%$. It is only 5 percentage points more than what $\mathrm{EH}$ alone explains.

I came to the conclusion that the degree of ethnic heterogeneity is by far the most important explanatory variable. Only 45 percents of the variation in EES remained unexplained. The unexplained variation is probably due to measurement errors, accidental factors, and various unknown cultural and environmental factors. Because many different and unrecognized factors affect the scale values of EES, it would be unrealistic to hope that any explanatory variable could explain all or nearly all of the variation in EES. The achieved explanation of $55 \%$ is already extremely high. The impact of ethnic nepotism explains why the scale of ethnic conflicts in Table 2 tends to be moderate or high in ethnically most divided societies and why it tends to be low in ethnically less divided societies. It is evident that ethnic nepotism is the cross-cultural background factor in the relationship between EH and EES. Ethnic nepotism explains by EH more than a half of the variation in EES in the 187 contemporary countries and predicts the persistence of ethnic conflicts to continue as long as there are ethnic divisions in the world. In other words, because of ethnic nepotism shared by all populations, the disappearance of ethnic conflicts, violence, and wars does not seem to be possible. Ethnic nepotism seems to persist as the crosscultural background factor of ethnic conflicts in all parts of the world. So the message of this article is that it would be useful for social scientists to take into account the impact of ethnic nepotism in their studies of ethnic and other conflicts.

\section{References}

Van den Berghe, P. L. (1981). The Ethnic Phenomenon. Westport, CT: Praeger.

The CIA World Factbook 2014 (2013). New York: Skyhorse Publishing.

Gardner, H. S. (1998). Comparative Economic Systems (2nd ed.). Philadelphia: Dryden Press.

Giddens, A. (1995). Sociology (2nd ed.). Cambridge: Polity Press.

Goetze, D. (2001). Evolutionary Theory, in Encyclopedia of Nationalism (Vol. 1). San Diego: Academic Press.

Gurr, T. R. (1993). Minorities at Risk: A Global View of Ethnopolitical Conflict. Washingon, DC: United States Institute of Peace Press. 
Hamilton, W. D. (1964). The Genetic Evolution of Social Behavior. I. Journal of Theoretical Biology, 7, 1-16.

2014 Index of Economic Freedom. http://www.heritage.org/index/about

Lynn, R., \& Vanhanen, T. (2012). Intelligence: A Unifying Construct for Social Sciences. London: Ulster Institute for Social Research.

Nafziger, E. W. (1997). The Economics of Developing Countries (3rd ed.). Upper Saddle River, N. J.: Prentice Hall.

Nyborg, H. (Ed.) (2013). Race and Sex Differences in Intelligence and Personality. A Tribute to Richard ynn at 80. London: Ulster Institute for Social Research.

Rupesinghe, K. (1988). Theories of Conflict Resolution and Their Applicability to Protracted Ethnic Conflict. In K. Rupesinghe (Ed.), Ethnic Conflict and Human Rights. Oslo: Norwegian University Press.

Rushton, J. P. (1986). Gene-Culture Coevolution and Genetic Similarity Theory: Implications for Ideology, Ethnic Nepotism, and Geopolitics. Politics and the Life Sciences, 4, 144-148.

Salter, F. (2003). On Genetics Interests: Family, Ethny and Humanity in an Age of Mass Migration. Frankfurt of Main: Peter Lang.

Smith, A. D. (1987). The Ethnic Origins of Nations. New York: Basil Blackwell.

Thayer, B. A. (2004). Darwin and International Relations: On the Evolutionary Origins of War and Ethnic Conflict. Lexington: University Press of Kentucky.

UNDP (2013). Human Development Report 2013. The Rise of the South: Human Progress in a Diverse World. New York: United Nations Development Programme.

Vanhanen, T. (1989). Politics of Ethnic Nepotism. 10th European Conference on Modern South Asian Studies, 28 September -1 October 1989, Venice.

Vanhanen, T. (1990). A Process of Democratization: A Comparative Study of 147 States, 1980-88. New York: Crane Russak.

Vanhanen, T. (1991). Politics of Ethnic Nepotism in India. In D. Weidemann (Ed.), Ethnicity and Political Development in South Asia (pp. 69-92). New Delhi: Manohar.

Vanhanen, T. (1992). Politics of Ethnic Nepotism: India as an Example. New Delhi: Sterling Publishers.

Vanhanen, T. (1997). Prospects of Democracy. A Study of 172 Countries. London and New York: Routledge.

Vanhanen, T. (1999). Ethnic Conflicts Explained by Ethnic Nepotism (Vol. 7). Stamford, Connecticut: JAI Press.

Vanhanen, T. (2009). The Limits of Democratization: Climate, Intelligence, and Resource Distribution. Augusta, Georgia: Washington Summit Publishers.

Vanhanen, T. (2012). Ethnic Conflicts: Their Biological Roots in Ethnic Nepotism. London: Ulster Institute for Social Research.

Wikipedia (2014). Conflict (Process). http://en.wikipedia.org/wiki/Conflict (process)

Wikipedia (2014). Ethnic Conflict. http://en.wikipedia.org/wiki/Ethnic_conflict 
Scientific Research Publishing (SCIRP) is one of the largest Open Access journal publishers. It is currently publishing more than 200 open access, online, peer-reviewed journals covering a wide range of academic disciplines. SCIRP serves the worldwide academic communities and contributes to the progress and application of science with its publication.

Other selected journals from SCIRP are listed as below. Submit your manuscript to us via either submit@scirp.org or Online Submission Portal.
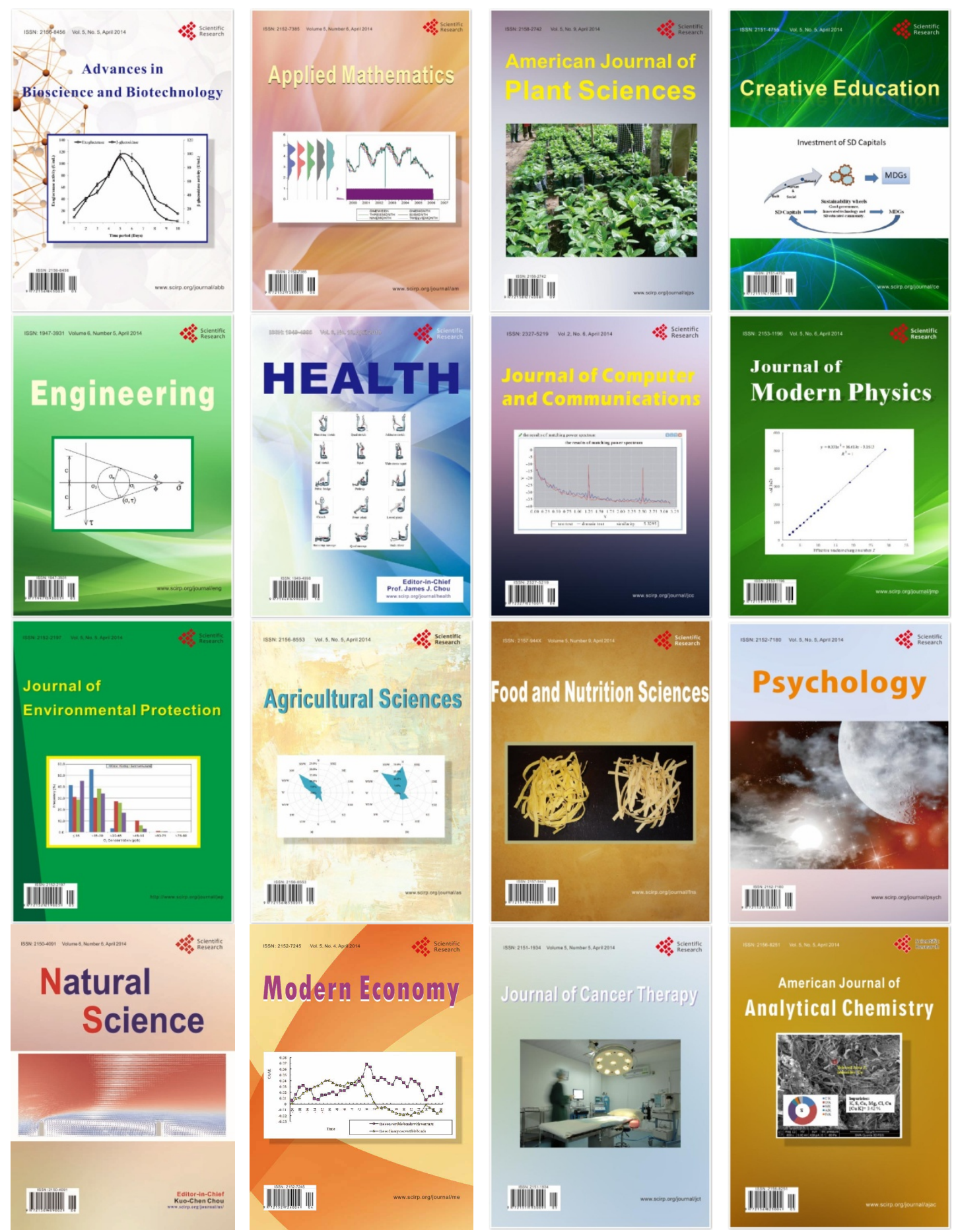